\title{
Ownership concentration, institutional ownership, and IPO underpricing: evidence from Indonesia Stock Exchange
}

\author{
Faculty of Economics and Business, \\ Universitas Gadjah Mada, \\ Jalan Humaniora 1, Bulaksumur, \\ Yogyakarta, 55281, Indonesia \\ Email: mamduhmh@ugm.ac.id \\ Email: agus_setiawan@ugm.ac.id \\ *Corresponding author
}

Mamduh M. Hanafi and Agus Setiawan

\begin{abstract}
Using 182 IPOs in Indonesia Stock Exchange from 2006-2015, we investigate IPO underpricing using agency theory framework. We use two dimensions of agency theory: ownership concentration and institutional ownership. We find that ownership concentration does not have effect on IPO underpricing, while institutional ownership negatively affects IPO underpricing. Institutional ownership seems to be able to monitor IPO underpricing, leading to smaller loss from IPO underpricing. We conduct further investigation. First, we find that institutional ownership does not moderate the effect of ownership concentration on IPO underpricing. Second, we find that the negative effect of institutional ownership on IPO underpricing is stronger when the level of institutional ownership is low. Higher level of institutional ownership seems to increase principal-principal agency conflict and to reduce monitoring effect of institutional ownership. Our results highlight the importance of ownership in company affairs.
\end{abstract}

Keywords: underpricing; ownership concentration; institutional ownership; agency conflict; Indonesia market; Indonesia.

Reference to this paper should be made as follows: Hanafi, M.M. and Setiawan, A. (2018) 'Ownership concentration, institutional ownership, and IPO underpricing: evidence from Indonesia Stock Exchange', Int. J. Governance and Financial Intermediation, Vol. 1, No. 1, pp.3-17.

Biographical notes: Mamduh M. Hanafi is an Associate Professor of Finance at Faculty of Economics and Business, Universitas Gadjah Mada. He also serves as the Director for Center for Capital Market Studies, Faculty of Economics and Business, Universitas Gadjah Mada. He teaches financial management subjects such as financial management, risk management, portfolio management. He also supervises several $\mathrm{PhD}$ students at Universitas Gadjah Mada. His main research interest is capital and financial market studies.

Agus Setiawan is an Associate Professor of Finance and Strategic Management at Department of Management, Faculty of Economics and Business, Universitas Gadjah Mada. He teaches financial management and strategic management. He was the former Vice Director of Master Management, Universitas Gadjah Mada, and held various administrative positions at Faculty of Economics and Business, Universitas Gadjah Mada. His main research interest is financial management and corporate governance. 


\section{Introduction}

Initial public offering (IPO) is an important means of financing for companies around the world. IPO is practically one of the most important steps in a history of a company. In Indonesia market, IPO market has been growing especially since year 1989. While in 1990, Jakarta Stock Exchange had around 60 listed companies, this number grows to around 480 companies in $2013 .{ }^{1}$ Despite its importance in company's history, IPO is not without drawbacks. One of the drawbacks commonly discussed in literature is IPO underpricing. IPO underpricing is usually defined as the difference between offer price and closing price at the first day of stock trading in secondary market. This underpricing is often viewed as a loss, at least a potential loss, since the issuing company foregoes opportunity to receive higher cash inflow as reflected in higher closing price at the first day of trading.

The consistent phenomenon of IPO underpricing prompts various theories to explain the phenomenon. IPO explanation can be grouped into four main theories: asymmetric model, institutional theory, ownership and control and behaviour finance (Ljungqvist, 2007). However, none of these theories provides full explanation for the IPO underpricing. The theory of asymmetric information in IPO markets seems to explain partially the IPO phenomenon, as evidenced by the findings that bulk of underpricing related gains goes to informed investors, uncertainty on firm's valuation increases underpricing, informed investors influence investment banks decision on IPO offer prices. However, Ritter and Welch (2002) argue that asymmetric information theories are unlikely to be primary explanations for IPO activities and underpricing. Instead, non-rational theories (such as behavioural finance) and agency explanations seem to offer better potential to explain IPO activity and underpricing.

This research attempts to use agency explanations to investigate IPO underpricing in Indonesia. As mentioned above, we believe that agency theory offers promising explanations for IPO underpricing, including in Indonesia. Indonesian context is characterised by low governance and low law enforcement (Johnson et al., 2001). ${ }^{2}$ In this environment, we believe agency problems become more pronounced, thus offers stronger potentials to explain various phenomena, including IPO underpricing. Evidence on the effect of governance variables on IPO underpricing in developed market has been reported extensively (for example, see Alavi et al., 2008). However, the evidence in emerging market is still relatively rare (Yong, 2007). This situation, along with a fact that governance system in emerging markets scores less than that for developed markets, prompts us to conduct this study.

We find that ownership concentration does not have any effect on IPO underpricing. We find that institutional ownership negatively affects IPO underpricing. We take further tests. We examine whether there is a nonlinear relationship between ownership structure and IPO underpricing and whether institutional ownership moderates the effect of ownership concentration on IPO underpricing. We do not find a nonlinear relationship, nor do we find that institutional ownership moderates the effect of ownership concentration on IPO underpricing. When we take further test for institutional ownership, we find that negative effect of institutional ownership is stronger when the level of institutional ownership is low. When the level is high, the negative effect disappears, suggesting that principal-principal agency conflict is more severe when the level of institutional ownership is high. 
We contribute to current literature by showing evidence on the effect of agency variables on IPO underpricing in emerging market. Yong (2007) suggests that relationship between underpricing and corporate governance attributes receives relatively little attention in the literature, especially in the Asian context. This paper takes a similar spirit to Darmadi and Gunawan (2013) who study the effect of governance variables on IPO underpricing in Indonesia market. Our results also support their findings. However, this paper is different from Darmadi and Gunawan (2013) in some aspects. While they use broad governance variables, such as board size, board independence, ownership concentration, ownership independence, to study their impacts on IPO underpricing, we use ownership concentration and institutional ownership variables and then attempt to analyse deeper into the nature of the effect of these variables on IPO underpricing. We study the moderation effect and the nonlinearity effect of ownership concentration and institutional ownership on IPO underpricing and the nonlinearity of the effect of institutional ownership on IPO underpricing.

We organise this paper as follows. Next section discusses literature review, followed by hypothesis development, research methodology, empirical findings and further analysis. Last section concludes.

\section{Literature review}

There are various theories that attempt to explain IPO underpricing. The theories can be classified as asymmetric information and symmetric information-based theories (Ritter and Welch, 2002). The asymmetric information stems from information asymmetry among parties involved in IPO, such as information asymmetry between issuers and underwriters, underwriters and informed traders and informed and uninformed traders.

Baron (1982) argues that there is information asymmetry between issuers and underwriters. Underwriters know much more than issuers. They have extensive experience in securities business, while for issuers; IPO is practically their first experience. Since underwriters know more, they have bargaining advantage, leading to underpricing. Information asymmetries between underwriters and informed traders are basis for various IPO theories, such as Book building mechanism (Sherman, 2005). Sherman (2005) argues that book building is a better IPO mechanism compared to auction and fixed price. In her model, underpricing is necessary to compensate informed traders to reveal their assessment of IPO values. The key to compensate informed traders is discretionary allocation held by underwriters. Underwriters give compensation for informed traders in the form of underpricing and repeated business. Information asymmetry between informed and uninformed traders is the basis for models such as in Rock (1986).

In Rock (1986) model, in which the setting is fixed price method, IPOs induce both informed and uninformed investors. Informed investors buy good IPOs, while informed investors by both good and bad IPOs. This situation leads uninformed investors to adverse selection problems. Underpricing is necessary to compensate uninformed investors. In book building method, informed investors make efforts to assess the true value of IPOs. Underpricing is used to compensate their efforts. In fixed method setting, underwriters do not have control over IPO allocation, while in book building, 
underwriters have discretionary on the IPO allocation. In fact, IPO allocation provides another form of compensation, i.e., good investors will be allocated future IPOs.

Various theories could be grouped into symmetric-based IPO theories, such as legal-liability theories and agency theories. In legal liability theory, underpricing is necessary to avoid legal problems faced by issuers. If offer price is much less than prices in aftermarket, creating significant loss for investors, then investors may be upset. Disappointed investors will sue issuers. There are various issues in IPO agency theories, such as allocation of shares, the role of monitoring such as venture capital in IPO underpricing, the effect of ownership on IPO or vice versa (the effect of IPO on ownership structure). This research attempts to take this line of study on IPO underpricing. More specifically, this research attempts to investigate the effect of ownership on IPO underpricing.

Booth and Chua (1996) argue that allocations of IPO to many investors increase liquidity. Brennan and Franks (1997) show that underpricing results in many investors and also lead to managers to entrench. However, Field and Sheehan (2001) do not find relationship between blockholders and IPO underpricing. Mello and Parsons (1998) argue that IPO shares are allocated diffusely with separate offer to blockholders. Stoughton and Zechner (1998) show that underpricing allows creation of a blockholder, inducing better monitoring. These papers basically show that ownership affects IPO underpricing through monitoring activities. Other direction of causality may also hold; IPO underpricing may affect monitoring activities. Ljungqvist and Wilhelm (2003) show a more direct causal relationship between ownership and IPO underpricing. IPO underpricing in dot.com era increases significantly. They show that the significant increase of IPO underpricing in dot.com era can be explained by changes in insider ownership, CEO stakes, equity stakes by $\mathrm{VC}$ and other corporations, frequency and magnitude of secondary sales. These changes lower monitoring incentives to control IPO underpricing.

Another interesting aspect of ownership in Indonesia is high ownership concentration and pyramidal ownership structure. On average, only $30 \%$ of outstanding shares are held by public investors, leaving $70 \%$ of outstanding shares for founding families. These patterns highlight other type of agency conflict which is principal-principal agency problem. In this situation, conflict between majority and minority shareholders becomes major issue. Using data from Taiwan, Lin and Chuang (2011) find that increasing family ownership and institutional ownership increases IPO underpricing. CEO duality also increases IPO underpricing, while employing independent outside directors mitigates IPO underpricing. For Indonesia evidence, Darmadi and Gunawan (2013) show that governance variables have association with IPO underpricing. Their regression coefficients show negative, positive and negative signs, for board size, board independence and ownership concentration, respectively.

\section{Hypotheses development}

The main issue in the effect of ownership on IPO underpricing lies in the issue of agency conflicts among parties involved in corporation. In western context, in which ownership tends to diffuse (Berle and Means, 1932), the agency conflict between principal and agents stands out. In diffused ownership, governance initiatives attempt to control managers from expropriating stockholders. However, in a concentrated ownership 
environment, stockholders will be able to control managers more effectively, for example by appointing relatives or close friend as managers. In this situation, there will be no conflict between principal and agents. Instead, other type of conflict arises, which is conflicts between different classes of investor. More specifically, in a concentrated ownership environment, conflicts between majority and minority shareholders stands out. Majority attempts to expropriate minority shareholders.

From this point, there are several directions can be explored relating to the issue of IPO underpricing. First, majority shareholders attempt to maximise gain from IPO, or minimise any losses from IPO, including the loss from IPO underpricing. Majority shareholders may not want to leave money on the table too much. Thus, we may expect that larger share of ownership, or the more concentrated ownership, the lower the underpricing, or negative relationship between ownership concentration and IPO underpricing. Second, another issue is that large ownership may want to block other larger shareholders from owning the shares, since large ownership may not want to share control. Underpricing can be used as a strategic tool to prevent other block shareholders to control companies. There are at least two possible scenarios. Majority shareholders want to have lower underpricing. Lower underpricing will not attract potential buyers, especially potential blockholders. Under this scenario, we can expect to have a negative relationship between ownership concentration and IPO underpricing. Third, we may have different scenario. More specifically, majority shareholders want to have large underpricing to attract more stockholders to buy the IPO. This situation results in more competition among potential shareholders and can be expected to lead to smaller block holding for shareholders buying IPO. Thus, original shareholders may be able to maintain their control over the company. We can expect to have positive relationship between ownership concentration and IPO underpricing in this situation. While we may have different scenarios, we believe that the first scenario, which is monitoring aspect from ownership concentration, is stronger than scenario of having IPO underpricing as a strategic tool. Hence, we propose the following hypothesis.

H1 Ownership concentration negatively affect underpricing.

Second aspect of ownership we investigate is institutional ownership. Institutional investors are different from individual investors in their ability to exercise monitoring on companies. Institutional investors tend to invest in large amount of money, hold substantial percentage of outstanding shares, while individual investors tend to hold much lower fraction of outstanding shares of a company. This results in different incentive to monitor a company. If underpricing is considered a loss to existing shareholders, including existing institutional investors, then institutional investors have higher incentive to monitor IPO process and attempt to minimise IPO underpricing.

However, Lin and Chuang (2011) argue that institutional investors in developing countries tend to hold much smaller fraction of stocks. For example, mutual fund in Taiwan accounts for only around $3.2 \%$ of total stock market, while in the USA; the percentage is around $24.5 \%$ (Khorana et al., 2005). The smaller percentage leads to lower incentive to monitor companies. Instead, other type of discipline measure, such sell shares, may be used to monitor the companies. Moreover, Lin and Chuang (2011) argue that in developing countries, institutional ownership is used as a means to create a pyramidal ownership structure. Pyramidal ownership is a more complex structure, may hinder transparency and vulnerable to expropriation of minority shareholders by majority 
shareholders. Thus, we expect an increase in principal-principal agency conflict. The increase in this conflict leads to increase in IPO underpricing. Thus, we can expect to have positive relationship between institutional ownership and IPO underpricing under this scenario. This argument is also consistent with Darmadi and Gunawan (2013) for Indonesia context. We use first scenario and propose following hypothesis.

$\mathrm{H} 2$ Institutional ownership negatively affects IPO underpricing.

We attempt to investigate further the nature of relationship between ownership concentration, institutional ownership and IPO underpricing. For the relationship between ownership concentration and IPO underpricing, we investigate whether there is a moderating effect in the relationship. We use institutional ownership as a possible moderating variable. Lemmon and Lins (2003) show that the negative effect of cash flow right leverage on firm performance shows up when managerial ownership presents. Using similar reasoning, we may expect that institutional ownership may strengthen the effect ownership concentration. While it is possible to have independent institutional before company issuing IPOs, we believe that institutional investors at the stage before IPO will be closely related to founding family ownership. Thus, we develop the following hypothesis.

H3 The negative effect of ownership concentration on IPO underpricing is stronger (more negative) when institutional ownership presents.

For the association between institutional ownership and IPO underpricing, we investigate the issue of possible nonlinear relationship between these two variables. Nonlinear relationship between ownership concentration and performance is well documented in literature (García-Meca and Sánchez-Ballesta, 2011). When ownership is dispersed, incentive to monitor becomes less since investors hold small fraction of shares. When stake becomes higher, incentive to monitor increases. However, when stake increases too high, there might occur conflict between controlling and minority shareholders. Controlling shareholders may expropriate minority shareholders leading to worse performance. Using the same reasoning, we develop the following hypothesis.

$\mathrm{H} 4$ There is a nonlinear relationship between institutional ownership and IPO underpricing. In high level of institutional ownership, negative effect of institutional ownership on IPO underpricing disappears.

\section{Research methodology}

\subsection{Sample and data collection}

We use 182 IPOs in Indonesia Stock Exchange (IDX) during year 2006-2015 as our sample. Our sample captures the most recent IPOs in Indonesia market. As of the end of 2015, there are 521 listed companies in IDX. We collect data on IPO prices: offer price, closing price, ownership concentration and institutional ownership. We also collect information for control variables: total assets and return on assets (ROA). We use following data sources for our data: Indonesian Capital Market Electronic Library, Bloomberg Financial Information Services and company prospectus. Table 1 shows 
operational definitions of variables used in this research. Ownership used in this paper refers to pre-IPO ownership (Alavi et al., 2008).

Table 1 Definition of variables used

\begin{tabular}{ll}
\hline Variable & \multicolumn{1}{c}{ Definition } \\
\hline Initial return & Natural logarithm of (closing price at day 1/offer price) \\
Ownership concentration & $\begin{array}{l}\text { Number of shares held by largest stockholders/number of total } \\
\text { outstanding shares }\end{array}$ \\
Institutional ownership & $\begin{array}{l}\text { Number of shares held by institutions/number of total outstanding } \\
\text { shares }\end{array}$ \\
Size & Natural logarithm of size \\
Return on assets (ROA) & Net income/total assets \\
\hline
\end{tabular}

Notes: This table reports definition of variables used in this research. The sample used is IPO from 2006-2015 in IDX.

\subsection{Model specification}

To investigate the effect of ownership concentration and institutional ownership, we run cross-sectional regression as follows:

$$
\begin{aligned}
\mathrm{UP}_{(\mathrm{i})}= & \alpha+\beta 1 \text { OwnCon }_{(\mathrm{i})}+\beta 2 \operatorname{InstOwn}_{(\mathrm{i})}+\beta 3 \mathrm{OwnCon}_{(\mathrm{i})} * \operatorname{InstOwn}_{(\mathrm{i})} \\
& +\Sigma \beta \text { Controlvariables }_{(\mathrm{i})}+\mathrm{e}_{(\mathrm{i})}
\end{aligned}
$$

where

UP underpricing

OwnCon ownership concentration

InstOwn institutional ownership

Subcript (i) refers to IPO/company.

Note that even though the nature of the model above is cross-sectional, our sample actually spans different years. Thus, our observations resemble time-series data; however, our observations are cross-sectional data. To investigate the moderating effect of institutional ownership on the effect of ownership concentration on IPO underpricing, we run the following model.

$$
\begin{aligned}
\mathrm{UP}_{(\mathrm{i})}= & \alpha+\beta 1 \text { OwnCon }_{(\mathrm{i})}+\beta 2 \operatorname{InstOwn}_{(\mathrm{i})}+\beta 3 \mathrm{OwnCon}_{(\mathrm{i})} * \operatorname{InstOwn}_{(\mathrm{i})} \\
& +\Sigma \beta \text { Controlvariables }_{(\mathrm{i})}+\mathrm{e}_{(\mathrm{i})}
\end{aligned}
$$

To investigate the nonlinear effect of institutional ownership on IPO underpricing, we run the following piece wise regression model.

$$
\begin{aligned}
\mathrm{UP}_{(\mathrm{i})} & =\alpha+\beta 1 \text { Inst_Own_Low }_{(\mathrm{i})}+\beta 2 \text { Inst_Own_High } \\
& +\beta 3 \text { OwnCon }_{(\mathrm{i})}+\Sigma \beta \text { Controlvariables }+\mathrm{e}_{(\mathrm{i})}
\end{aligned}
$$

where 
Inst_Own_Low institutional ownership if institutional ownership $<=$ break point Ins_Own_Low $=$ break point if institutional ownership $>$ break point

Inst_Own_High break point if institutional ownership $<=$ break point

Inst_Own_High (institutional ownership - break point) if institutional ownership $>$ break point.

The break point for the piece wise regression in this paper is determined using visual inspection.

\section{Empirical findings}

\subsection{Descriptive statistics}

Table 2 reports descriptive statistics of variables used in this paper.

Table 2 Descriptive statistic of initial returns, ownership concentration, institutional ownership, size and ROA

\begin{tabular}{lcccccc}
\hline Variable & Mean & Median & $\begin{array}{c}\text { Standard } \\
\text { deviation }\end{array}$ & Minimum & Maximum & $N$ \\
\hline $\begin{array}{l}\text { Initial return } \\
\begin{array}{l}\text { Ownership } \\
\text { concentration }\end{array}\end{array}$ & 0.1020 & 0.0858 & 0.3734 & -2.0818 & 1.0986 & 182 \\
$\begin{array}{l}\text { Institutional } \\
\text { ownership }\end{array}$ & 0.7591 & 0.8010 & 0.2323 & 0.2525 & 1.0000 & 182 \\
$\begin{array}{l}\text { Size (million Rp) } \\
\text { Return on assets }\end{array}$ & $2,685,322$ & $1,049,866$ & $5,228,189$ & 229 & $44,992,171$ & 182 \\
\hline
\end{tabular}

Notes: This table reports descriptive statistics of variables used in this research. The definitions of the variables are reported in Table 1. Total sample is 182 IPO from year 2006-2015.

In Table 2, we observe that the average of initial return is around $10 \%$. This number is smaller than 23\% IPO underpricing reported by Husnan et al. (2014) or $22 \%$ IPO underpicing reported by Darmadi and Gunawan (2013), although IPO underpricing tends to have large variation. For example, Ljungqvist (2007) reports IPO underpricing in world markets that varies from 5\% in Luxembourg to around $60 \%$ in Poland market and around $90 \%$ for Malaysia ownership in Indonesia tends to be concentrated. The average of ownership concentration is around $75 \%$. This number is similar to the average of outstanding shares sold to public, which is around $30 \%$. The average of institutional investors is around $10 \%$ with a minimum of zero and the largest is $100 \%$. The average tends to be lower compared to that in Taiwan, which is around 24\% (Lin and Chuang, 2011 ) and around 5\% from previous study in Indonesia context (Darmadi and Gunawan, 2013).

\subsection{Baseline results}

In this section, we present our main findings. Table 3 shows regression results for this paper. 
Table 3 Regression results of the effect of ownership concentration and institutional ownership on IPO underpricing

\begin{tabular}{lccc}
\hline & $(1)$ & $(2)$ & $(3)$ \\
\hline Intercept & 0.2794 & 0.4449 & 0.3719 \\
& $(0.2909)$ & $(0.0568)$ & $(0.1525)$ \\
Ownership concentration & 0.1113 & - & 0.0741 \\
& $(0.3470)$ & & $(0.5227)$ \\
Institutional ownership & & -0.3366 & -0.3299 \\
& & $(0.0012)$ & $(0.0016)$ \\
Ln total assets & -0.0149 & -0.0185 & -0.0174 \\
& $(0.3840)$ & $(0.2643)$ & $(0.2972)$ \\
ROA & -1.0632 & -0.9861 & -0.9704 \\
& $(0.0052)$ & $(0.0078)$ & $(0.0090)$ \\
Adjusted R-squared & 0.0371 & 0.0876 & 0.0845 \\
F-value & 3.32 & 6.79 & 5.18 \\
Prob & $(0.0210)$ & $(0.0002)$ & $(0.0006)$ \\
$\mathrm{N}$ & 182 & 182 & 182 \\
\hline
\end{tabular}

Notes: This table reports regression results of the effect of ownership concentration and institutional ownership on IPO Underpricing. Definitions of variables used are explained in Table 1. IPO sample in IDX is collected from 2006-2015. P-values are in parentheses.

In column (1), ownership concentration does not affect IPO underpricing, even the sign is positive which contradicts our expectation. ROA negatively affects IPO underpricing. Profitability measure turns out to be the strongest predictor for IPO underpricing. In column (2), institutional ownership negatively affects IPO underpricing. ROA still shows a negative effect on IPO underpricing. In column (3), we combine ownership concentration and institutional ownership in a single equation. The negative effect of institutional ownership still persists. ROA consistently has negative effect on IPO underpricing.

Our findings of insignificance result for variable ownership concentration does not support literature that shows that ownership concentration improves performance (McConnell and Servaes, 1990; Agrawal and Mandelker, 1990; García-Meca and Sánchez-Ballesta, 2011; Shleifer and Vishny, 1997). Although other opposing literature shows that large shareholders may have incentives to use their controlling position to expropriate minority shareholders (Lee, 2008). However, our findings are consistent with previous study using Indonesia data (Darmadi and Gunawan, 2013), who find negative relationship between institutional ownership and IPO underpricing and insignificant relationship between ownership concentration and IPO underpricing. Note, that we use initial return or underpricing instead of company's value measured by price to book value or Tobin's Q. Initial return may have different characteristics than performance measure. Initial return may not measure performance per se. It may measure other things, such as compensation for related parties. For example, Barry and Jennings (1993) argue that initial return is a compensation for investors who bear risks in primary markets, as shown by significant open to offer return (see also Rock, 1986; Sherman, 2005). 
The negative effect of institutional ownership may suggest that institutional investors monitor the IPO pricing and do not want to leave money on the table too much. This result is in contrast with other findings that report positive relationship between IPO underpricing and institutional ownership (for example, see Lin and Chuang, 2011). They argue that, in Taiwan, institutional ownership is used to build pyramidal ownership, which may increase principal-principal agency conflict. The positive relationship between institutional ownership and IPO underpricing found in their paper suggests that investors demand compensation for holding shares of companies with high principal-principal agency conflict. Although pyramidal ownership is also common in Indonesia, we do not find a similar pattern.

\section{Further analysis: moderating effect for ownership concentration and nonlinear effect for institutional ownership}

We want to take further analysis on the effect of ownership concentration and institutional ownership on IPO underpricing. The first issue for ownership concentration is a nonlinear relationship between ownership concentration and IPO underpricing. The nonlinear relationship between ownership concentration and Firm's performance is well documented in current literature. We attempt to investigate whether this pattern also shows up for IPO underpricing. Figure 1 shows the plot of ownership concentration on IPO underpricing.

Figure 1 Plot of ownership concentration on IPO underpricing (see online version for colours)

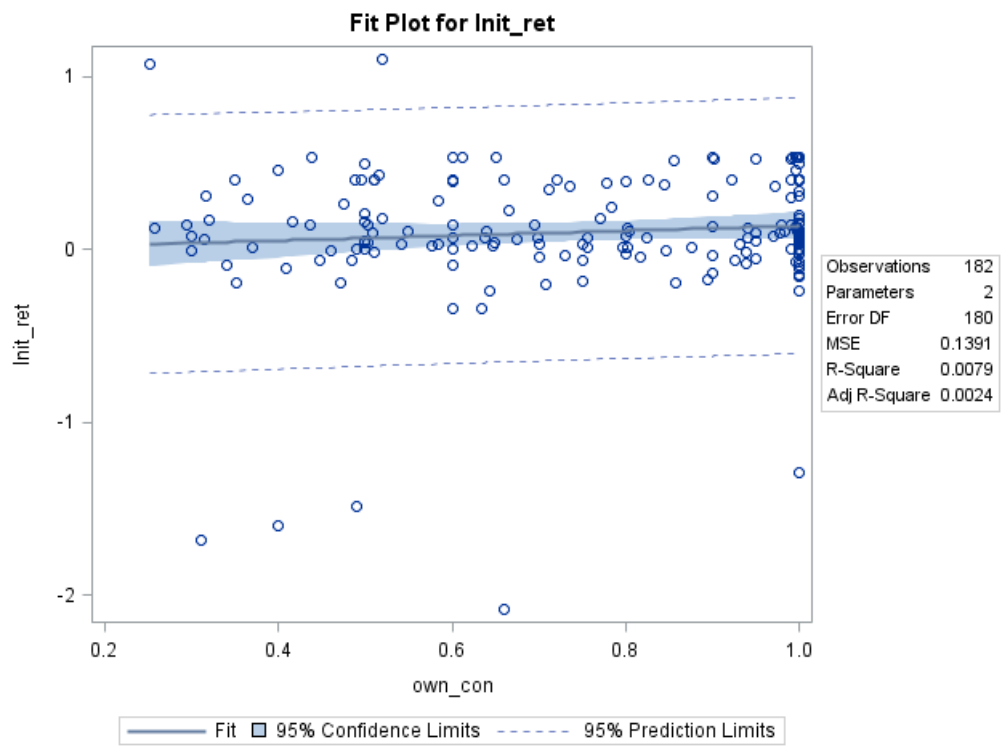

Notes: This figure shows a plot of ownership concentration on IPO underpricing. Definitions of variables are explained in Table 1. Sample is IPOs in IDX from 2006-1015. 
Examining Figure 1, we seem to find a no nonlinear relationship between ownership concentration and IPO underpricing. Other possible explanation for the non-significant effect of ownership concentration is the presence of moderating effect. We conjecture that the relationship between ownership concentration and IPO underpricing changes at different level of institutional ownership. More specifically, we expect that the relationship disappears when level of institutional ownership is high.

Table 4 shows regression results of moderating effect of institutional ownership on the effect of ownership concentration on IPO underpricing.

Table 4 Moderating effect of institutional ownership on the effect of ownership concentration on IPO underpricing

\begin{tabular}{lcc}
\hline Variables & $(1)$ & $(2)$ \\
\hline Intercept & 0.1055 & 0.4245 \\
& $(0.3023)$ & $(0.1108)$ \\
Ownership concentration & 0.0477 & 0.0293 \\
& $(0.7056)$ & $(0.8148)$ \\
Institutional ownership & -0.7638 & -0.6646 \\
& $(0.0404)$ & $(0.0747)$ \\
Ownership concentration * institutional ownership & 0.5477 & 0.4374 \\
& $(0.2416)$ & $(0.3486)$ \\
Ln total assets & - & -0.0187 \\
& & $(0.2641)$ \\
ROA & - & -0.9246 \\
& & $(0.0136)$ \\
Adjusted R-squared & 0.0571 & 0.0839 \\
F-value & 4.65 & 4.32 \\
Prob & $(0.0037)$ & $(0.001)$ \\
N & 182 & 182 \\
\hline
\end{tabular}

Notes: This table shows regression results that include institutional ownership as a moderating variable on the effect of ownership concentration on IPO underpricing. Definitions of variables are explained in Table 1. Ownership concentration * institutional ownership is a multiplication of ownership concentration and institutional ownership. P-values are in parentheses.

The table shows no moderating effect. The coefficient for ownership concentration * institutional ownership is not significant statistically at conventional level.

Next issue is related to institutional ownership. We want to investigate whether the effect of institutional ownership on IPO underpricing is not constant across our observations. Figure 2 show the plot of institutional ownership on IPO underpricing.

In Figure 2, we observe the negative relationship between institutional ownership and IPO underpricing seems to be stronger when the level of institutional ownership is lower. Visual inspection seems to suggest that the break point of 0.8 seems promising. To investigate formally this issue, we run piecewise regression as defined in model (3). We then run regression that includes variables Inst_Own_Low and Inst_Own_High. Table 5 shows regression results. 
Figure 2 The plot of institutional ownership on IPO underpricing (see online version for colours)

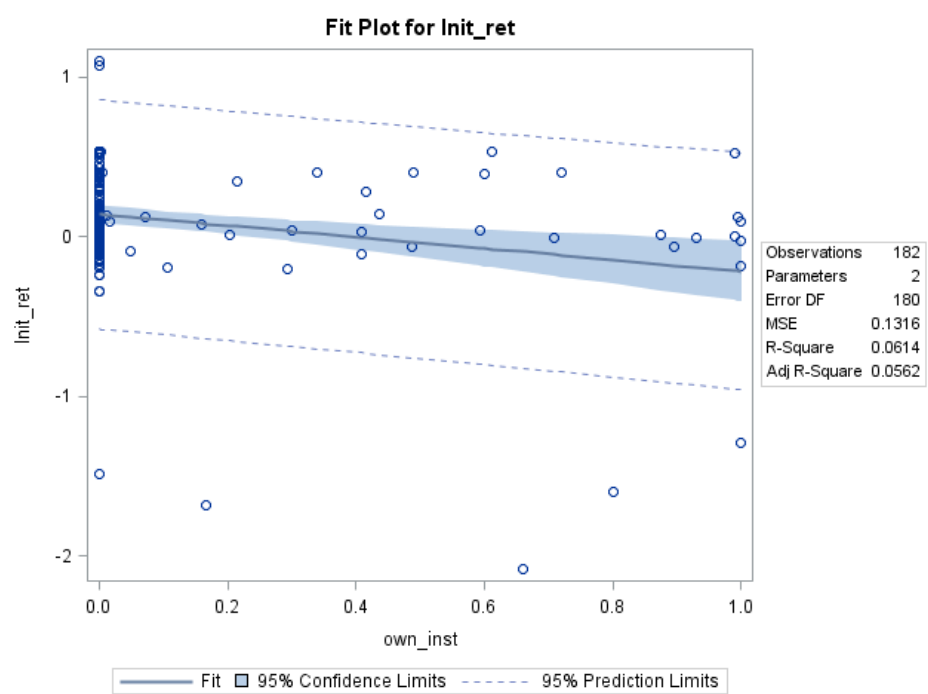

Notes: This figure shows a plot of institutional ownership on IPO underpricing.

Definitions of variables are explained in Table 1. Sample is IPOs in IDX from 2006-1015.

Table 5 Piecewise linear regression on the effect of institutional ownership on IPO underpricing

\begin{tabular}{lcc}
\hline Variables & $(1)$ & $(2)$ \\
\hline Intercept & -0.2936 & -0.2638 \\
& $(0.7206)$ & $(0.7504)$ \\
Inst_Own_Low & -0.5048 & -0.4906 \\
& $(0.0026)$ & $(0.0051)$ \\
Inst_Own_High & 0.8909 & 0.8131 \\
& $(0.3525)$ & $(0.4151)$ \\
Ownership concentration & & 0.0347 \\
& & $(0.7731)$ \\
Ln total assets & -0.0164 & -0.0161 \\
& $(0.3222)$ & $(0.3364)$ \\
ROA & -0.9478 & -0.9434 \\
& $(0.0105)$ & $(0.0112)$ \\
Adjusted R-squared & 0.0910 & 0.0863 \\
F-value & 5.53 & 4.42 \\
Prob & $-(0.0003)$ & $(0.0008)$ \\
$\mathrm{N}$ & 182 & 182 \\
\hline
\end{tabular}

Notes: This table shows piecewise regression on the effect of institutional ownership on IPO underpricing. We define Inst_Own_Low = Institutional ownership if institutional ownership $<=0.8$, and Ins_Own_Low $=0.8$ if Institutional ownership $>0.8$. Inst_Own_High $=0.8$ if institutional ownership $<=0.8$ and Inst_Own_High $=($ institional ownership -0.8$)$ if institutional ownership $>0.8$. Break point is 0.8 . Definitions of variables are explained in Table 1. P-values are in parentheses. 
Table 5 seems to confirm our conjecture that the effect of institutional ownership is not constant across the level of institutional ownership. When institutional ownership is below 0.8 , the effect of institutional ownership on IPO underpricing is significantly negative. The negative effect disappears when institutional ownership is above 0.8 . When institutional ownership increases to certain level, it is possible that principal-principal agency conflict increases; the monitoring effect of institutional investors disappears.

\section{Conclusions and limitation}

This paper attempts to investigate the effect of ownership concentration and institutional ownership on IPO underpricing. Our research is motivated by the lack of full explanation for IPO underpricing. Ritter and Welch (2002) argue that the most promising explanation for IPO underpricing may come from non-rational and agency explanations. We use two variables to measure agency conflicts in corporations: ownership concentration and institutional ownership.

We find that ownership concentration does not affect IPO underpricing, while institutional ownership negatively affect IPO underpricing. We conduct further tests. For ownership concentration, we check for possible nonlinear effects of ownership concentration on IPO underpricing. We also test whether institutional ownership moderates the effect of ownership concentration on IPO underpricing. We do not find significant results for these tests. For institutional ownership, we test whether the effect is not constant across level of institutional ownership. Piecewise regression shows that the negative effect of institutional ownership on IPO underpricing is stronger when the institutional ownership is lower than 0.8 . When the level of institutional ownership increases to the level above 0.8 , the negative effect disappears. This result suggests that monitoring effect of institutional investors disappears in high level of institutional ownership. Principal-principal conflicts may increase at high level of institutional ownership. From policy perspective, our study highlights the importance of ownership in companies' affairs. Ownership affects many aspects of companies including IPO underpricing.

Our study leaves two unresolved issues. First is endogeneity issue. Reverse causality between ownership and performance is well documented in literature. For the same reasoning, one may argue there exists a reverse causality between ownership and IPO underpricing. However, further analysis seems to suggest that the reverse causality does not seem to exist in our specification. More specifically, we use pre-IPO ownership data as our ownership variables (ownership concentration and institutional ownership). Since pre-IPO ownership exists before IPO underpricing, we believe that the causality is one direction: ownership affects IPO underpricing. We may, however, have possible endogeneity issues arising from omitted variables that may bias our specification. For example, underpricing and ownership may relate to risk or some other common variables. This issue is more difficult to identify the direction, let alone to tackle. We leave this issue for further study. Second, our observations contain outlier data which may reduce generalisability of our findings. While the easiest way to deal with this issue is to remove outlier data, we do not follow this way. We believe that IPO underpricing, by its nature, has large variation (for example, see Loughran and Ritter, 2004; Ljungqvist, 2007). Thus outlier data reflect a genuine IPO underpricing phenomenon; hence, we do not remove 
outliers from our sample. Still, treatment for outliers warrants further investigation. We leave this issue for further study.

\section{Acknowledgements}

We are grateful to anonymous referees, seminar participants at Faculty of Economics and Business, Universitas Gadjah Mada, and especially Irwn Trinugroho (the Editor) for helpful comments. We also gratefully acknowledge financial support from Faculty of Economics and Business, Universitas Gadjah Mada. All errors are our own.

\section{References}

Agrawal, A. and Mandelker, G.N. (1990) 'Large shareholders and the monitoring of managers: the case of antitakeover charter amendments', Journal of Financial Quantitative Analysis, Vol. 25, No. 2, pp.143-161.

Alavi, A., Pham, P.K. and Pham, T.M. (2008) 'Pre-IPO ownership structure and its impact on the IPO process', Journal of Banking \& Finance, Vol. 32, No. 11, pp.2361-2375.

Baron, D.P. (1982) 'A model of the demand for investment banking advising and distribution services for new issues', Journal of Finance, Vol. 37, No. 4, pp.955-976.

Barry, C. and Jennings, R. (1993) 'The opening price performance of initial public offerings of common stock', Financial Management, Vol. 22, No. 1, pp.54-63.

Berle, A. and Means, G. (1932) The Modern Corporation and Private Property, MacMillan, New York, NY.

Booth, J.R. and Chua, L. (1996) 'Ownership dispersion, costly information and IPO underpricing', Journal of Financial Economics, Vol. 41, No. 2, pp.291-310.

Brennan, M.J. and Franks, J. (1997) 'Underpricing, ownership and control in initial public offerings of equity securities in the UK', Journal of Financial Economics, Vol. 45, No. 3, pp.391-413.

Darmadi, S. and Gunawan, R. (2013) 'Underpricing, board structureand ownership: an empirical examination of Indonesian IPO firms', Managerial Finance, Vol. 39, No. 2, pp.181-200.

Field, L.C. and Sheehan, D.P. (2001) Underpricing in IPOS: Control, Monitoring or Liquidity?, Working Paper, Pennsylvania State University.

García-Meca, E. and Sánchez-Ballesta, J.P. (2011) 'Firm value and ownership structure in the Spanish capital market', Corporate Governance: The International Journal of Business in Society, Vol. 11, No. 1, pp.41-53.

Husnan, S., Hanafi, M.M. and Munandar, M. (2014) 'Price stabilization and IPO underpricing: empirical study in Indonesia Stock Exchange', Journal of Indonesian Economy and Business, Vol. 29, No. 2, pp.129-141.

Johnson, S., Boone, P.D., Breach, A. and Friedman, E. (2001) Corporate governance in the Asian financial crisis', Journal of Financial Economics, Vol. 58, Nos. 1-2, pp.141-186.

Khorana, A., Servaes, H. and Tufano, P. (2005) 'Explaining the size of mutual fund industry around the world', Journal of Financial Economics, Vol. 78, No. 1, pp.145-185.

Lee, S. (2008) 'Ownership structure and financial performance: evidence from panel data of South Korea', Corporate Governance and Control, Vol. 6, No. 2, pp.254-267.

Lemmon, M. and Lins, K.V. (2003) Ownership structure, corporate governance and firm value: evidence from the East Asian financial crisis', Journal of Finance, Vol. 58, No. 4, pp.1445-1468.

Lin, C-P. and Chuang, C-M. (2011) 'Principal-principal conflicts and IPO pricing in an emerging economy, Corporate Governance: An International Review, Vol. 19, No. 6, pp.585-600. 
Ljungqvist, A. and Wilhelm, W.J. (2003) 'IPO pricing in the dot-com bubble', Journal of Finance, Vol. 58, No. 2, pp.723-752.

Ljungqvist, A.P. (2007) 'IPO underpricing', in Eckbo, B.E. (Ed.): Handbook of Corporate Finance: Empirical Corporate Finance, Elsevier, Amsterdam.

Loughran, T. and Ritter, J.R. (2004) 'Why has IPO underpricing changed over time?', Financial Management, Vol. 33, No. 3, pp.5-37.

McConnell, J.J. and Servaes, H. (1990) 'Additional evidence on equity ownership and corporate value', Journal of Financial Economics, Vol. 27, pp.595-612.

Mello, A.S. and Parsons, J.E. (1998) 'Going public and the ownership structure of the firm', Journal of Financial Economics, Vol. 49, No. 1, pp.79-109.

Ritter, J.R. and Welch, I. (2002) 'A Review of IPO activity, pricing and allocations', Journal of Finance, Vol. 57, No. 4, pp.1795-1828.

Rock, K. (1986) 'Why new issues are underpriced', Journal of Financial Economics, Vol. 5, Nos. 1-2, pp.187-212.

Sherman, A.E. (2005) 'Global trends in IPO methods: book building vs. auctions', Journal of Financial Economics, Vol. 78, No. 3, pp.615-649.

Shleifer, A. and Vishny, R. (1997) 'A survey of corporate governance', Journal of Finance, Vol. 52, No. 2, pp.737-783.

Stoughton, N.M. and Zechner, J. (1998) 'IPO-mechanisms, monitoring and ownership structure', Journal of Financial Economics, Vol. 49, No. 1, pp.45-77.

Yong, O. (2007) 'A review of IPO research in Asia: what's next?', Pacific-Basin Finance Journal, Vol. 15, No. 3, pp.253-275.

\section{Notes}

1 Jakarta Stock Exchange and Surabaya Stock Exchange merge to become IDX in year 2007.

2 Recent survey still puts Indonesia at the last ranking in governance quality, for example, see 'Singapore leads Asia-Pacific corporate governance ranking' Asia-First.com, September 30, 2016. 